\title{
Audit Fee, Human Resources, and Audit Quality of Financial Statements
}

\author{
${ }^{1}$ Lindrianasari, ${ }^{2}$ Einde Evana, ${ }^{3}$ Ayu Fatmasari \\ Email: lindrianasari@feb.unila.ac.id, eindeevana@yahoo.co.id, fatmasariayu@gmail.com \\ Accounting Department, the University of Lampung, Sumantri Brojonegoro Street No.1, \\ Bandar Lampung, Indonesia ${ }^{1,2}$, Ministry of Finance of the Republic of Indonesia, Dr. \\ Wahidin Raya Street No 1 Jakarta, Indonesia ${ }^{3}$
}

\begin{abstract}
This study aims to provide empirical evidence about the impact of audit fees on the audited quality of financial statements. Human resources become a moderating variable to provide understanding of the importance of adequate human resources in completing audit tasks. The contribution to be made in this study is to initiate the issuance of new rules that limit the number of clients in each public accounting firms and auditor. The research data used are all public accounting firms in Indonesia, the period 2016-2018 obtained from the Ministry of Finance of the Republic of Indonesia. The final data used in the study were 979 public accounting firms in the 2016-2018 period. The findings of this study indicate that the higher audit fees received by public accounting firms and auditors tend to reduce the audit quality of financial statements.
\end{abstract}

Keywords: Audit fee, Human Resources, Sanction, Audit Quality.

\section{Introduction}

The restatement case that has to be carried out at several SOEs in Indonesia in 2017 and 2018 is a dark side of the auditor's performance and has reduced the expectations of stakeholders in the company and also the accounting profession. Consumer News and Business Channel Indonesia (CNBC Indonesia) has reported on the problems with PT Garuda Indonesia (GIAA) which must restate the 2018 financial statements and coordinate with its auditors to update opinions (https://www.cnbcindonesia.com/ market/20190622085606-1779999/polemik-berlanjut-garuda-harus-restatement-laporan -keuangan). Previously, BUMN Holding for a cement company, PT Semen Indonesia Tbk (SMGR) also had to make a restatement of the income statement in the 2017. The SMGR restatement showed the company's current year's net profit in the 2017 was corrected around $\mathrm{Rp} 393.02$ billion. The restatement reported that the company's net profit for 2017 , which was previously recorded at Rp 2.04 billion, fell $19.24 \%$ to $\mathrm{Rp} 1.62$ billion (https://www.cnbcindonesia.com/market/ 20190510144013-17-71727/semen-indonesia-restatement-lapkeu-2017-laba-turun). This situation shows the caution of GIAA and SMGR external auditors in carrying out their obligations as auditors of financial statements.

This study aims to provide empirical evidence to the government about the impact of audit fees on the audit quality of financial statements that will ultimately have an impact on sanctions. The contribution of this study is to initiate the issuance of new rules that limit the number of clients in each public accounting firms (hereinafter in brief as CPA firms) and auditor. The more clients of CPA firms, the more the quality of audited reports decreases and ultimately will result in sanctions. The implementation of this regulation is expected to improve the quality of audited financial statements, increase the credibility of CPA firms and 
more importantly, provide guarantees for investing in companies in Indonesia. The government also needs to set the ideal ratio of CPA firms workload and auditor taking into account the human resources working at CPA firms, which are in-charge in the audit work. That way, there are clear limits that must be adhered to by the CPA firms and the Auditor in accepting work, in order to maintain the integrity of the audited financial statements, as a product of the CPA firms and the auditor. This study found empirical evidence that the higher audit fees received by public accounting firms and auditors tend to reduced the audit quality of financial statement. The high audit fee shows the high workload in audit work carried out by CPA firms (it will eventually lead to time pressure in carrying out audit tasks). The results of this study also show that the negative effect caused by audit fees on the audit quality of financial statements will decrease with the increasing number of qualified human resources working in CPA firms.

Furthermore, this paper will present a literature review that explains the theoretical assumptions of the research rationale. Previous research was also collaborated with theory for the development of strong hypotheses. The research method presents data and data sources, variables and their measurements, samples, and econometrics used to answer research questions. The results of statistics, conclusions, research implications are explained and acknowledgments in closing this paper.

\section{Literature Review}

The stimulation theory and response theory[1] and interactionism theory[2] describe conditions when a person is in workload. The three theories explain that workload on a person can create work pressure and this will affect physical and mental health, affect the quality of work, create failure in control of work, and ultimately will affect the overall performance of individuals. In the issue of workload in public accounting firms, this theory can be used to explain that the workload of auditors and or public accounting firms will create work pressure, reduce the quality of work and ultimately will reduce the quality of audited financial statements.

The job demand control model explains the definition of stress as an output of the demands of achieving one's work and how much control they can exercise over their responsibilities in the job. The pressure to complete work with the ability to control the completion of work, plays a role in producing quality work. This process can create four quadrants of job positions; passive, active, low level pressure, and high level pressure[3]. Someone will be in the quadrant of certain job positions due to a combination of factors that create the stress, and this is very contingent. That is, the responses given by each worker to the stress trigger factors are not the same. Psychologically, many things will affect someone in providing job performance. Some factors that cause stress include: the level of interruption (leader, regulator, client), time pressure, conflicting demands, time available to complete work, work procedures, proportion of work performed under pressure, amount of work, level of concentration needed, a slowdown in work caused by the need to wait for someone else, and the number of teams working on the job.

There are two factors that affect the stress level of working individuals[3]. First, high work demands are caused by the work environment. In the work environment, stressors can take the form of time pressure, demands from superiors, workload, conflicts at work, number of teams, and others. Second, the control capabilities that employees have over their responsibilities and how they are committed to doing the work assigned to them. Stress theories continue to develop over time[4]. However, stress theory is fundamentally classified into three approaches, namely the stress stimulus model, the stress response model, and the 
transactional stress model[5][6]. Overall these models indicate that stress (stress) will reduce performance.

A study found that when workload occurs there will be an increase in the probability of restatement of financial statements[7]. Workloads will also trigger dysfunctional behaviors[8] and work stress[9][10] and time pressure[7] resulting in decreased audit quality for a number of individual auditors. Contingency theories or approaches are also widely used in previous studies to explain the need to consider the availability of in-charge human resources in audit work. The high workload makes the auditor have little time or even lead to time pressure in carrying out audit tasks in certain company financial statements. High workloads indicate a large portfolio of auditor clients[8].

An investigation conducted by the Securities and Exchange Commission (SEC) on Enron greatly surprised financial markets. The SEC revealed that in addition to the $\$ 25$ million audit fee conducted by Andersen, Andersen also received another \$27 million from Enron in the same year for consulting fees. This raises questions about conflicts of interest in CPA firms. This conflict of interest further reduces audit quality on the client's financial statements[11]. This meeting shows that the higher the fees received by CPA firms the lower the quality of the audits they conduct. When the workload is reflected in the audit fees received by the CPA firms, this research assumes that the higher the workload, the higher the audit fees obtained by the CPA firms. Based on previous theory and research, this research formulates the first hypothesis for Model 1 research as follows:

Ha.1: the higher the audit fee, the lower the audit quality on the financial statements.

The contingency approach also explains that there are factors that determine and become a condition of interdependence. Team performance is highly dependent on the dimensions of the task and the composition of the team working[12]. The existence of a team greatly influences the success of teamwork. So that people believe about how their relies on the cooperation and the strength of teamwork. At the very least, the number of teams that work (especially if the interactions are good) will improve the quality of work. Previous studies have suggested that when individuals collaborate with team, it will produce stronger, better understanding, problematic interpersonal relationships, and work becomes more effective[13] and creates good internal control[14]. These studies explain that the amount of labor (human resources) will greatly affect the improvement of the quality of work, especially in jobs that have a large time and accountability limit.

In this research issue, the number of HR who working in audit work will greatly affect the quality of audited financial statements. This study uses a contingency approach with the number of HR as a moderating variable, and assumes that the number of HR can minimize the impact of workload on the quality of audited financial statements. In another hand, abnormal audit costs are negatively related to the likelihood that financial statements are restated[5]. Good internal control has improved the quality of audited financial statements even though there are abnormal (high) audit fees. These results also confirm that there are things that will control, high audit costs on the quality of financial statements. Our contingency hypothesis is formulated as follows:

Ha.2: the greater number of human resources involved in audit, the lower the impact of audit fees on the audit quality of financial statements. 


\section{Method}

This research uses quantitative methods. The data used are (1) total revenue (fee) of public accounting firms; (2) the amount of human resources; (3) sanctions received by public accounting firms. The econometrics model used to test the impact of workload on the quality of audited financial statements is ordinary least square (regression). Research data obtained from the PPPK (Financial Professional Development Center) Ministry of Finance of the Republic of Indonesia. This research uses big-data so that the data filling format is needed caution. All CPA firms in Indonesia have an obligation to report the total number of auditor clients working in their respective offices. Meanwhile, the variables to be measured are audit fees, working human resources, and the quality of audited financial statements that are proxied by sanctions received by each auditor and or public accounting firm. For the moderating variable is the amount of human resources in a public accounting firm.

The statistical formulation for the 2 nd model of this study is:

Where:

$$
\mathrm{Y}=\alpha+\beta 1 X 1+\beta 2 X 2+\beta 3 X 1 * X 2+e
$$

$\mathrm{Y}=$ sanctions (Audit quality of financial statements)

$\mathrm{X} 1=$ the number of public accounting firm audit fees

$\mathrm{X} 2=$ the number of workers in public accounting firm

$\alpha$ is a constant, a variable outside the research model whose value is fixed.

$\beta 1 ; \beta 2 ; \beta 3$ is a regression coefficient that shows the magnitude of the impact or effect of each independent variable on the dependent variable.

\subsection{Operational Variables}

The dependent variable of this study is audit quality of the financial statements. Audit quality on financial statements is measured by how many sanctions received by the auditor or CPA firms. The more sanctions received indicate the lower the results of audits of the financial statements. Audit fees are predictor variables for sanctions received by auditors. Audit fees are measured using the amount of CPA firms's income in a year. The assumption used in this study is that the higher the audit fee, the more work the auditor /CPA firms receives. More work will degrade the quality of audit work. This study uses sanctions as a measure of audit quality by referring to Government Regulation Number 20 of 2015 concerning CPA firms. This study uses the sanctions criteria as set out in the following criteria for sanction weights used in this study:

a) 0 = no sanctions;

b) 1 = recommendation sanctions;

c) 2 = warning sanctions;

d) 3 = sanctions limiting the provision of services to a type of entity;

e) $4=$ sanctions limiting the provision of certain services; and

f) $5=$ sanction of license suspension.

g) $6=$ revocation sanction.

All sanctions are determined by the quality of audits conducted by CPA firms. The higher the value of sanctions, the lower the quality of audits by the CPA firms. The financial statement audit period in Indonesia is relatively the same from January to April each year. Human resources are variables that use a contingency approach (moderation variable). Where HR has an accounting and in-charge background in audit work becomes a moderating variable. HR is predicted to play its role in minimizing the negative impact of audit fees on the quality of the results of audited financial statements. 


\section{Data Processing, Result, and Discussion}

The data of this study are public accounting firms that have complete data used in this study. There are 1260 objects that can be observed from data obtained from the Ministry of Finance of the Republic of Indonesia, 2019. The final object of this study (which has complete data) is 979 in three years of observation, namely 2017-2018. The number of observations was 279 in 2016, 321 observations in 2017, and 379 observations in 2018.

Table 1. Statistika Deskriptif

\begin{tabular}{llrrrr}
\hline & N & Minimum & Maximum & \multicolumn{1}{c}{ Mean } & Std. Deviation \\
\hline Audit_Fee & 979 & 15.67 & 27.38 & 20.6145 & 1.75356 \\
Human_Resources & 979 & 1.00 & 831.00 & 22.2390 & 70.87020 \\
Audit_Qual & 979 & -13.00 & .00 & -.1982 & .90982 \\
Valid N (listwise) & 979 & & & & \\
\hline
\end{tabular}

The results of the statistical description of the data used in this study indicate that the audit fee (in Ln) obtained on average in a sample of research in a public accounting firm in Indonesia is 20.61. The lowest total audit fee is 15.67 at the Hasbuh \& Basri public accounting firm in 2016 and the highest at 27.38, namely the Jenny A. \& Kristina PR public accounting firm in 2017. For the amount of human resources - HR (Human_Resources), on average the sample of public accounting firm research samples in Indonesia is 22 people. The lowest total HR value is at 1 (in many public accounting firms in Indonesia) and the highest is at 831, namely at the Satrio Bing Eny \& Rekan public accounting firm in 2016. The audit quality value of financial statements, which is proxied from the number of sanctions received shows on average, public accounting firms in Indonesia have sanctions (sanctions or their performance in auditing financial statements. However, the sanctions received are still at the warning limit in this research notated. Table 1 shows the results of descriptive statistics in this research data.

\subsection{Hypothesis testing}

The hypothesis of this study was tested using multiple regression. The relationship between research variables showed a value of $22.3 \%$. This result shows that the contribution of the independent variable is $22.3 \%$ on the audit quality on the financial statements conducted by public accounting firms. The relationship value also shows the ability of audit fees and human resources as predictors of audit quality, although there are still $77.7 \%$ of explanations that can be provided by other variables outside of this research variable.

Anova test shows an $\mathrm{F}$ value of 17.047 with a significance of $0.00 \mathrm{~b}$ indicating that this research model is fit, so that hypothesis testing (testing between research variables) is feasible. The test results of the research model with predictors from Audit Fee (AF), Human Resources (HR), and moderation between AF_HR also indicate the value of fit (sig. F Change 0,000). From the entire preliminary test as a condition for using the OLS tool, it can be concluded that the data used in this study can continue testing. Further research hypothesis testing is performed on data that has passed the classical assumption test and the model fit-test. The multiple regression was conducted on the final research data about 979 public accounting firms in Indonesia in the 2016-2018 period.

The results of tests show the regression coefficient between audit fees and audit quality of financial statements conducted by the auditor on his client is negative. The t-statistic value of 3.217 and significant 0.001 indicates that the higher audit fees obtained by public accounting firms from their audit work, the lower the audit quality of the financial statements they produce, which in turn has an impact on sanctions. Since it is assumed that audit fees are influenced by workloads, the greater audit fees result in a decrease in the quality of audit 
work. This result supports the first hypothesis of the study which states that the higher the audit fee in CPA firms and Auditor, the lower the quality of audited financial statements. The results support a study found an increase in the probability of restatement of financial statements when the workload in CPA firms is increase[7]. The findings of this study also confirm the emergence of dysfunctional behaviors described[8], work stress[10], and time pressure[7]. The functional behaviors tend to decrease audit quality in individual auditors. All of these findings indicate that the higher audit fees will reduce audit quality of the financial statements. The higher audit fee shows the higher audit workload, than ultimately leads to time pressure in carrying out audit tasks in the financial statements.

The second hypothesis of this study states that the more number of human resources involved in audit work, the lower the negative impact of the audit fee effect on the audit quality of financial statements. This hypothesis wants to show that qualified HR at CPA firms will greatly assist the audit work. No matter how heavy the audit burden, good human resources will be able to support the work to produce higher quality audit work. Regression testing on the moderation model in table 5 shows that the negative effect of audit fees on audit quality decreases with the number of qualified HR in CPA firms. If the results of the test between audit fees and audit quality of financial statements are negative with a t-statistic value of -3.217 and a significance of 0.001 , then moderated by qualified human resources in CPA firms, the negative impact will weaken. SDM succeeded in changing the t-statistic from -3.217 to -2.134 , with the original significance of 0.001 being 0.033 . Although it is still clear that the workload will greatly affect the quality of audits carried out by CPA firms on the financial statements of its clients, but qualified human resources will greatly help the work to be better.

The results of this study support previous research whose explains that team performance is highly dependent on the dimensions of the task and the composition of the team that is working[12]. In addition, the existence of a team greatly influences the success of teamwork. When individuals work together in teamwork, it will produce stronger interpersonal relationships, better understanding of problems, and work to be more effective[13] and can also create good internal control[14]. This study also supports the contingency theory that has been advanced by previous researchers and assumes that the number of human resources can minimize the impact of workload on the audit quality of financial statements[12]. The results of this study successfully support the second hypothesis of this study.

\section{Conclusion}

\section{Conclusion}

This study found empirical evidence that the higher the audit fee received by CPA firms, the more likely it would be to reduce audit quality in financial statements. The high audit fee shows the high workload in the audit work and will ultimately lead to time pressure in carrying out audit tasks. The results of this study also showed that the negative effect caused by audit fees on audit quality of financial statements decreased with the increasing number of qualified human resources working in public accounting firms. These results indicate that performance achievement is highly dependent on the dimensions of the task and the composition of the working team and the existence of the work team. Therefore, the number of qualified human resources in audit work will greatly affect audit quality. Stronger and better interpersonal relationships, and those who better understand the problem, will produce more effective work. This is why the number of HR working together in a work team can improve audit quality. 
Acknowledgments. Funding for this research was obtained from the University of Lampung and data obtained from the Ministry of Finance of the Republic of Indonesia. We would like to thank those who helped this research until completed.

\section{References}

[1] H. Selye, "Stress without Distress," in Psychopathology of Human Adaptation, Springer \{US\}, 1976, pp. 137-146.

[2] R. H. Price, "Healthy Work: Stress, Productivity, and the Reconstruction of Working Life. Robert Karasek, Töres Theorell," Q. Rev. Biol., vol. 66, no. 4, pp. 525-526, Dec. 1991, doi: $10.1086 / 417423$.

[3] C. Carraro et al., Green Accounting in Europe. Edward Elgar Publishing Limited, 2005.

[4] N. T. L. Gaol, "Teori Stres: Stimulus, Respons, dan Transaksional," Bul. Psikol., vol. 24, no. 1, p. 1, Jun. 2016, doi: 10.22146/bpsi.11224.

[5] S. Unnithan, "Stress \{\textemdash\} Perspectives and Processes\$mathsemicolon\$ D. Bartlett: Open University Press, Buckingham (1998), vii\$ \mathplus\$173 pp., \{ltextsterling\}14.99," Behav. Res. Ther., vol. 38, no. 7, p. 750, Jul. 2000, doi: 10.1016/s0005-7967(99)00116-3.

[6] C. Baumann, C. Baumann, and E. Lundmark, "Corporate social responsibility in financial services: A comparison of Chinese and East Asian banks vis-à-vis American banks," Int. J. Bank Mark., vol. 31, no. 6, pp. 420-439, 2013, doi: 10.1108/IJBM-05-2012-0054.

[7] A. I. Blankley, D. N. Hurtt, and J. E. MacGregor, "The Relationship between Audit Report Lags and Future Restatements," \{AUDITING\} A J. Pract. Theory, vol. 33, no. 2, pp. 27 57, May 2014, doi: 10.2308/ajpt-50667.

[8] D. M. López and G. F. Peters, "The Effect of Workload Compression on Audit Quality," \{AUDITING\} A J. Pract. Theory, vol. 31, no. 4, pp. 139-165, Nov. 2012, doi: 10.2308/ajpt-10305.

[9] T. O. West et al., "Cropland carbon fluxes in the United States: Increasing geospatial resolution of inventory-based carbon accounting," Ecol. Appl., vol. 20, no. 4, pp. 1074 1086, 2010, doi: 10.1890/08-2352.1.

[10] H. Yan and S. Xie, "How does auditors' work stress affect audit quality? Empirical evidence from the Chinese stock market," China J. Account. Res., vol. 9, no. 4, pp. 305319, Dec. 2016, doi: 10.1016/j.cjar.2016.09.001.

[11] J. Tackett, F. Wolf, and G. Claypool, "Sarbanes-Oxley and audit failure," Manag. Audit. J., vol. 19, no. 3, pp. 340-350, Apr. 2004, doi: 10.1108/02686900410524355.

[12] B. Beersma, J. R. Hollenbeck, S. E. Humphrey, H. Moon, D. E. Conlon, and D. R. Ilgen, "Cooperation, competition, and team performance: Toward a contingency approach," Acad. Manag. J., vol. 46, no. 5, pp. 572-590, 2003, doi: 10.2307/30040650.

[13] C. K. W. De Dreu and L. R. Weingart, "A Contingency Theory of Task Conflict and Performance in Groups and Organizational Teams," in International Handbook of Organizational Teamwork and Cooperative Working, John Wiley \& Sons Ltd, 2008, pp. 151-166.

[14] A. Jokipii, "Determinants and consequences of internal control in firms: a contingency theory based analysis," J. Manag. Gov., vol. 14, no. 2, pp. 115-144, Mar. 2009, doi: 10.1007/s10997-009-9085-x. 